\title{
Growth delay due to insulin-like growth factor type 1 deficiency
}

INSERM

\section{Source}

INSERM. (1999). Orphanet: an online rare disease and orphan drug data base. Growth delay due to insulin-like growth factor type 1 deficiency. ORPHA:73272

Growth delay due to insulin-like growth factor I deficiency is characterised by the association of intrauterine and postnatal growth retardation with sensorineural deafness and intellectual deficit. 